\title{
A Confucian Framework For Categorizing Elementary Pre-service Teachers' Expectations Of Their Science Methods Course
}

Richard P. Hechter, University of North Dakota, USA

Lynette D. McGregor, Wartburg College, Iowa, USA

\begin{abstract}
Science teacher educators strive to improve their elementary science methods courses through modification of existing content, activities, or teaching technique. But what do the enrolled preservice teachers expect to learn from these courses and how do they expect to learn it? This study qualitatively examines preservice elementary teachers' expectations of: their science methods course, the activities of the course, the instructor, and of themselves. Upon entry to the elementary science methods course at two Midwestern colleges in the Fall term of 2008, preservice teachers $(n=37)$ were asked to articulate what they expected to learn and how they expected to learn it. Their written responses were coded and categorized into one of three areas: imitation, reflection, and experience. These three categories, as a philosophical theoretical framework, stem from Confucius who suggested that the aforementioned areas were the keys to gaining wisdom. It is important, that as science teacher educators, we understand how our students expect to gain wisdom about their profession from our course. It is our contention that preservice teachers' expectations of their elementary science methods course prior to the commencement of the course have far reaching effects into the context in which they engage within the course.
\end{abstract}

Keywords: Elementary Science Methods, Confucian wisdom, Preservice Teacher, Expectations

\section{INTRODUCTION}

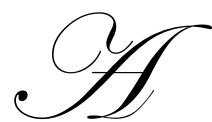

s students file into our science methods courses this term, what are they thinking about relative to our course? Do they ponder what they are going to learn or are they more concerned with the interference of the mid-term with their spring-break plans? If we are honest and have our fingers on the pulse of today's student population; probably the later is true. However, understanding what our students expect from our course makes it easier to address those issues and expectations as we move through the course plans and goals that have been set. Mueller and Skamp (2003) advise that it is imperative teacher educators actively listen and authentically respond to teacher candidates' expectations as these expectations represent the spectrum of how preservice teachers expect to learn to teach. This study listens to teacher candidates articulate their expectations and categorizes them into discernible areas for further analysis.

\section{Background}

The background section of this paper will provide relevant literature for 1) college student expectations of their courses; 2) preservice teachers' expectations for their courses; 3) Confucian philosophy of acquiring wisdom and the application of this to science teacher education. These three aspects provide the context and theoretical framework for this study. 


\section{College Student Expectations}

Our use of the phrase student expectations is limited to meaning: what students expect will happen in the class, what they expect to do as a learner, and what they expect the instructor to do. Research examining student expectations of their college courses in these terms has been minimal. Some have related grade expectations to course enjoyment (Remedios, Liberman and Benton (2000). Allgood, Risko, Alvarez, and Fairbanks (2000) have related increased student self-efficacy and motivation to their understandings of the courses' expectations. Brinthaupt (2004) extrapolates this notion by providing students enrolled in upper-level Psychology courses with realistic course expectations - both positive and negative. He reported that students referred to these instructor-provided expectations through out the course and found them helpful, accurate, and balanced reflections of the course.

When students have expectations that are not congruent with the objectives of the course, students struggle to understand those objectives; if they even recognize them at all. Kirschner, Meester, Middelbeek, \& Hermans (1993) found that college students taking a science laboratory course encountered what they expected when completing lab activities. Interestingly, this was irrespective of what was actually presented for objectives and content. Students enrolled in four different science laboratory courses (Physics, Biology, Chemistry, Biology II) were given a Student Anticipation List (SAL) prior to the lab activity. On this list were the objectives they might have anticipated encountering when completing the lab. The same list was given following the lab activities but asked students which objectives they had encountered (Student Encounter List- SEL). Regardless of the science content (physics, biology, or chemistry), students taking part in the lab activities identified content they expected, regardless if the objective was included in the lesson or not. The reverse was also true; if they did not anticipate specific content in the lesson, then they perceived they had not encountered it. Their anticipations were highly related $(\mathrm{p}<0.001)$ to their perceived encounters. While this may be true for science content courses, the question arises if preservice science teachers hold the same expectations for science methods courses.

\section{Preservice Teachers' Expectations of a Science Methods Course}

Mueller \& Skamp (2003) conducted interviews with preservice elementary education teachers at various points through out their two year education program. The initial point of contact was prior to the science methods course. The focus question asked at the interview was general: What will it mean to teach elementary science? Students were not asked specifics about their expectations of the course. A second interview occurred following the completion of the course. In this interview, students were more explicit in commenting if their expectations for the course were or were not met. Three themes emerged from these early interviews: 1) Science methods courses were designed with fun learning activities for creating positive feelings about science and for the teaching of science; 2) Science methods courses needed a practical component for putting the theoretical concepts learned into practice; and 3) Science methods courses included current research and theory that needs to be learned before putting it into practice. These three findings can be framed in the context provided by the philosophical teaching of Confucius.

\section{Confucian Philosophy and the Science Methods Course}

Philosophical influences on educational design, practice, and theory form a palette of broad spectrum. Within the rational postulates of Plato's Idealism through Peirce's purpose of thought in action in Pragmatism to the individual free will of Existentialism, these approaches contribute valuable insight into educational policy, decision making, progress and delivery. These approaches drive the tenets of the educational process in different ways depending on the nature of the education. Chinese philosopher Confucius taught that wisdom can be gained via three methods: Reflection, which is the highest method for gaining wisdom; Imitation, which is the easiest method; and, Experience which is the bitterest method (Hall, Quinn, \& Gollnick, 2008). Current trends in teacher education science methods courses aim to provide teacher candidates with all of the methods to gain wisdom and hone the craft of science teaching. It is thus imperative to highlight the nature of a science methods course.

Anderson (1997) provided useful insight into the dynamics of science methods courses in suggesting that they include: 1) "a launching pad for a career-long process of professional development" (p.269); 2) "foundation for 
a successful student teaching experience" (p. 269); and 3) "the linchpin of the teacher education program" (p. 269). Anderson's (1997) research provides context of the science methods course in which the participants of this study are enrolled. This study utilized the teachings of Confucius, specifically the methods for gaining wisdom, as the framework for categorizing preservice teachers' expectations of the elementary science methods course into one of the following three areas: Reflection, Imitation, and Experience. Each grouping is further expanded below.

\section{Reflection}

Hatton and Smith (1995) purported that reflection is an intended goal of many teacher education programs. The scope of preservice teacher reflection is well documented in the literature (Fendler, 2003; Melville 2008). With the notion of teacher as reflective practitioner (Bullough and Gitlin, 1994; Cochran-Smith, 2001; Hoban 2000, Schon, 1983) deeply entranced in modern educational thought, the involvement of reflection is a critical part of teacher education. Calderhead (2006) noted that reflection in teacher education stems from the writings of Dewey (1933). Calderhead (2006) defined reflection as, "active persistent and careful consideration of any belief or supposed form of knowledge in the light of grounds that support it and the further conclusions to which is tends" (p.9). Habermas (1973) contended that reflection was the vehicle to become aware of one's context. As preservice teacher candidates progress through their programs of study it is likely that they will have encountered reflection within their courses even prior to their science methods course. As a result, preservice teachers would likely expect the same actions to occur in the science methods class. Mueller and Skamp (2003) advocate for creating learning environments, activities, and assessment within teacher education programs dedicated to reflection.

\section{Imitation (Modeling)}

Torff (1999) suggests that since the teacher is perceived as the person with the knowledge, and students are in a course to obtain, engage in, and learn that knowledge, then the teacher acts as a model for the students. Therefore, the teacher becomes the model to imitate. This assertion manifests in science teacher education as preservice teachers' expectation to be shown by the instructor or peers a method for teaching science that they can imitate and model once in their field experiences or student teaching.

Hawkins (1990) suggests that teachers will teach science in the way they were taught science, the proverbial 'loop in history'. Jarrett (1998) indicated that inquiry-based, hands-on activities modeled in a science methods course, motivated teachers to implement similar activities in their own classroom. Bleicher \& Lindgren (2005) interviewed preservice teachers that had been taught science content using hands-on activities in a learning cycle format as part of a science methods course. These students indicated after experiencing science taught in that format, they had a greater comfort level with and increased confidence in implementing similar lessons in an elementary classroom.

\section{Experience}

Bargh and Schul (1980) suggest that the act of preparing to teach is a complex process. This preparation utilizes elevated levels cognitive skill in the form of developing mental constructs and schema that aid in both teacher and student learning. This process is completed within the elementary science methods course in the form of peer teaching and preparation for field experiences. Kelly (2000) asserts that preservice teachers develop greater insight into the dynamics of science teaching and learning through experiencing the roles of both teacher and learner in formal and informal situations. Wagner and Gansemer-Topf (2005) assert that, "peer teaching is a valuable, even critical, experience for students in a professional education program" (p.198). We could not agree more.

\section{Statement Of The Problem}

"It is essential for teacher educators to listen and respond to future teachers' expectations from the outset.without knowledge of teacher candidates' expectations, a teacher educator cannot possibly address concerns at this early and crucial stage (prior to method courses)" (Mueller \& Skamp, 2003, p. 438). Few studies identifying the expectations of elementary education majors for their science methods courses were found when reviewing the 
literature. Before we can implement changes to our course design, teaching strategies, or learning activities, we need to answer: What do elementary education majors expect from their science methods course from the outset?

\section{Purpose Of The Study}

Science teacher educators strive to improve their elementary science methods courses through modification of existing content, activities, or teaching techniques. But what do the enrolled preservice teachers expect to learn from these courses and how do they expect to learn it? The purpose of this study was to qualitatively examine preservice elementary teachers' expectations of their science methods course in terms of how the planned activities relate to learning how to become an elementary level science teacher.

\section{Significance Of The Study}

Kirschner, et al, (1993) found students' expectations of the content they would encounter in a course affected the way in which they experienced the content. An assumption could be made that this could also be the case for their expectations of teaching strategies as well as learning activities. From a constructivist perspective of learning, students enter our science methods course already in possession of previous knowledge about teaching and science education. This information influences the expectations of the course and their learning in the course. "As a result of numerous years as students, teacher candidates will have diverse expectations about what they will learn to teach" (Mueller \& Skamp, 2003). However, once in the course, what they take from the course is determined by their expectations. Interestingly, Kirschner, et al. (1993) found that, "Experience does not give rise to expectations, if anything expectations determine experience" (p. 178).

To synthesize these ideas in terms of this study's question: the experience preservice teachers have prior to the methods course determine their expectations of the course; and their expectations determine the experience they have during their methods course. Understanding that students find what they expect and remain ignorant of what they did not expect has implications not only for the content of our elementary science methods course, but also the teaching strategies and learning activities.

\section{RESEARCH METHODS}

This section of the paper will provide an overview of the methodology used in this study. It will include sections on the setting, course and participants as well as the procedures and research design.

\section{Settings, Course And Participants}

This study took place as part of the elementary science methods course at two Midwestern colleges during the Fall session of 2008. One of the colleges was a state institution with $\sim 15,000$ students, with both undergraduate and graduate programs in education. The other college was a private, liberal arts institution with 2000 students with only an undergraduate program in education. Both institutions are located in the mid-west United States. The elementary science methods courses both delivered similar content with emphasis on science pedagogy, coupled with a field practicum in local schools. However, one course met once a week for three hours while the other met three times a week for 65 minutes each time. The researchers were also the instructors of their respective courses. Participants $(n=37)$ in this study were preservice elementary teachers enrolled in one of the two elementary science methods courses during the Fall term of 2008. The population of both courses shared similar characteristics; predominantly female (82\%), Caucasian (90\%), and all juniors and seniors.

\section{Procedures And Research Design}

Upon entry to the course, participants were asked to articulate via written answers to open-ended questions, their specific expectations of the course. The survey (Appendix A) took approximately ten minutes to complete. It was completed prior to either instructor giving any course-specific information to the students; for example the syllabus or course objectives. Individuals were assigned unique numerical codes to ensure confidentiality. 
Of the seven questions on the response instrument, the first five were open ended questions which allowed students to articulate their responses as they saw fit. The open ended responses were coded and categorized using a grounded theory approach. A mixed methods approach was used to analyze the data. Questions six and seven used a rating scale of 1 to 5. A score of 1 represented a low rating and score of 5 represented a high rating. Distribution patterns were used to analyze the scale based questions. Student responses on the survey were categorized using Confucius' three methods for gaining wisdom.

\section{RESULTS}

\section{Qualitative Data}

Listed below are some examples of the categorized responses given by the preservice teachers for Question \#2 on the survey. What do you expect for activities that will help that learning take place? Each of the researchers independently coded the responses with an inter-rater reliability of $97 \%$. The preservice teachers' responses were categorized into the three Confucian methods (Reflection, Imitation and Experience) for gaining wisdom. Examples of the preservice teacher answers included in each group are provided below.

\section{Reflection}

The first grouping contained responses that aligned with the notion of Reflection; as in the cognitive and affective nature of teaching and learning the teaching of science. Examples given of Reflections responses given by students include:

- $\quad$ Lesson plans.

- $\quad$ Plenty of feedback.

- $\quad$ Lesson planning, science standards for each grade level, cooperative learning, unit.

- $\quad$ They are able to talk about the procedure outcome \& know why it worked or didn't work.

- $\quad$ Explained thoroughly so we can understand the process of how they are taught.

- $\quad$ A lot of discussion \& problem solving.

- $\quad$ From the activities we do in class I would like to learn a way to apply the activity or modify it to use in an elementary classroom.

Imitation (Modeling)

The second grouping contained responses that aligned with the notion of Imitation; as in preservice teachers' either participating in activities designed by the professor or peers, but not teaching the lessons themselves. Examples given of Imitation responses given by students include:

- $\quad$ Modeling. I like to see things done in order to understand \& learn.

- $\quad$ Lots of hands-on activities and learning experiences.

- $\quad$ I would like to see examples of science activities by you \& my peers. I need lots of ideas on lessons.

- $\quad$ They (the activities) should be educational and very hands-on so we can actually put ourselves in the students' places.

- $\quad$ Examples of lesson plans, presentations by my peers to see what they are coming up with.

\section{Experience}

The third grouping contained responses that aligned with the notion of experience; as in the preservice teacher acting in the role of teacher either in the form of peer teaching, science learning centers, or field experiences. Examples of Experience responses given by students include.

- $\quad$ Teaching of actual elementary science lessons. 
- $\quad$ Implementing them (activities to do with students) to our class.

\section{Quantitative Data}

Responses were examined quantitatively to allow insight into distribution trends and patterns. Preservice teacher comments were organized into three different analyses: 1) Quantifying the number of students responding in each group or combination of groups; 2) Frequency distribution of the responses by group; and 3) Direct count of the total number of responses in each of the three groups.

The first method of analysis was to categorize the responses into a group (ie: Reflection), or in some cases, groups (ie: Reflection + Imitation). With three possible means of gaining wisdom, and the possibility of preservice teachers expecting one, two or all three from their science methods course; there are therefore seven possible combinations of groups. The combinations of expectations which are shown in Figure 1 include; Reflection only $(\mathrm{R})$, Imitation only (I), Experience only (E), Reflection and Imitation $(\mathrm{R}+\mathrm{I})$, Reflection and Experience $(\mathrm{R}+\mathrm{E})$, Imitation and Experience $(I+E)$, and Reflection, Imitation, and Experience $(R+I+E)$. The results of this analysis are represented below.

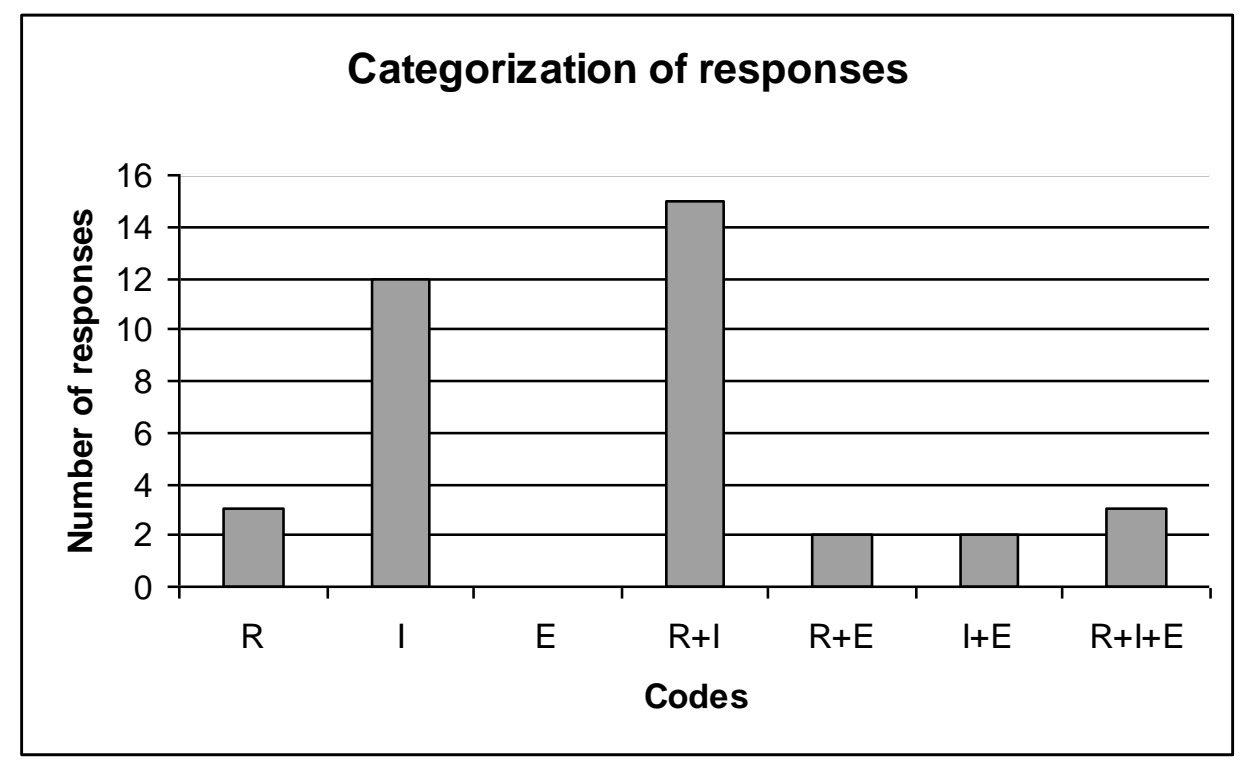

Figure 1: Categorization of preservice teacher responses $(n=37)$ into three Confucian groups.

With 15 of the 37 students reporting that they expect to gain wisdom of science teaching via Reflection and Imitation $(\mathrm{R}+\mathrm{I})$ within the science methods course, this grouping was clearly the most frequent response. The sole group with no responses was Experience. We find this very interesting, and will discuss it later in this paper.

The second method of quantitative analysis in this study was to determine the frequency of responses that were categorized into only one group for gaining wisdom, as compared to expecting two or in some cases all three. The results of this analysis are represented below. 


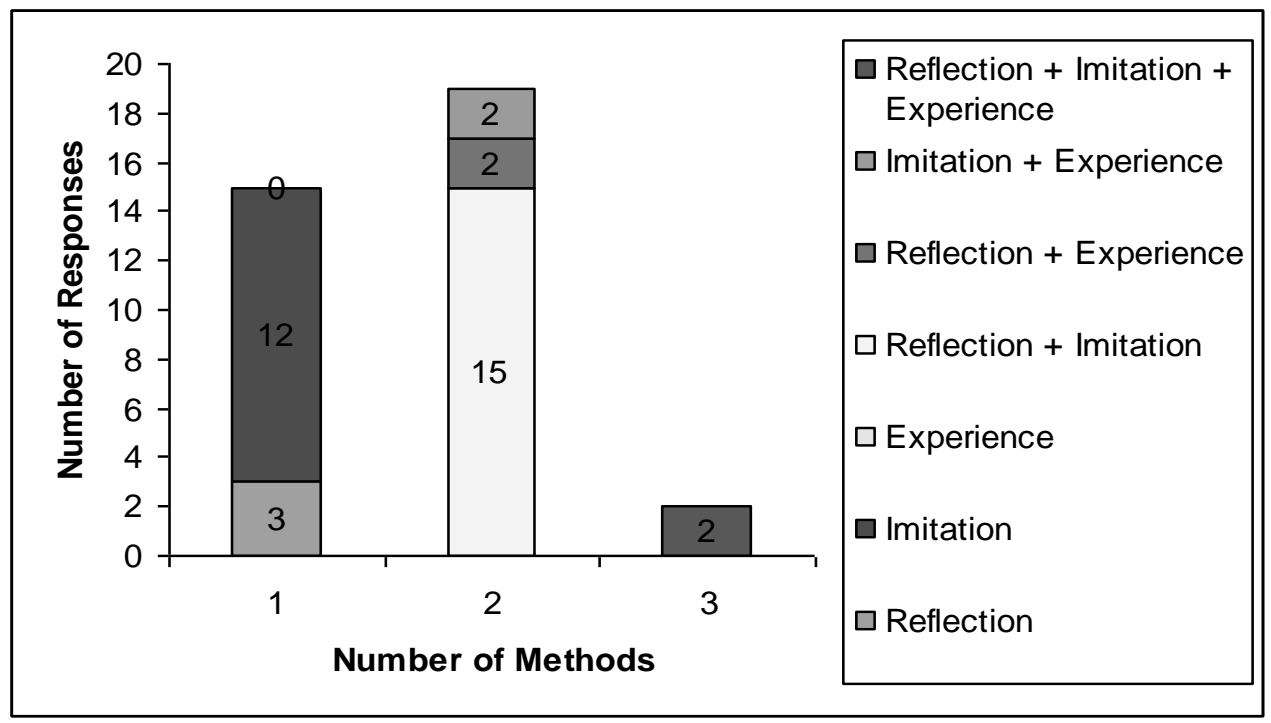

Figure 2: The number of Confucian methods represented in a preservice teachers' response $(\mathrm{n}=37)$.

Fifteen preservice teachers' responses indicate that they expect to learn via only one means of gaining wisdom. An example of this response includes; I expect to see examples of lessons written in a lesson plan format. I expect the activities to be a combination of visual \& verbal teaching. This was categorized into the group Imitation.

Gaining wisdom via two means had the highest number of responses with nineteen. An example of this response includes; Activities where we act as the students. Other lab like activities where we have the role of instructor. This response was categorized into the Imitation and Experience (I + E) grouping.

The fewest preservice teacher responses included an expectation to learn through all three areas of Reflection, Imitation, and Experience. An example of this response includes; I do not want to simply read from the book and then come to class to hear a lecture and take notes. I expect to do some teaching as well as have you model activities / teaching to us. Hands on activities that we can use on our own students would be great.

The third part of the analysis in this study was to find the number of times each of the methods for gaining wisdom appeared in the responses. The results are presented below in the form of percentages.

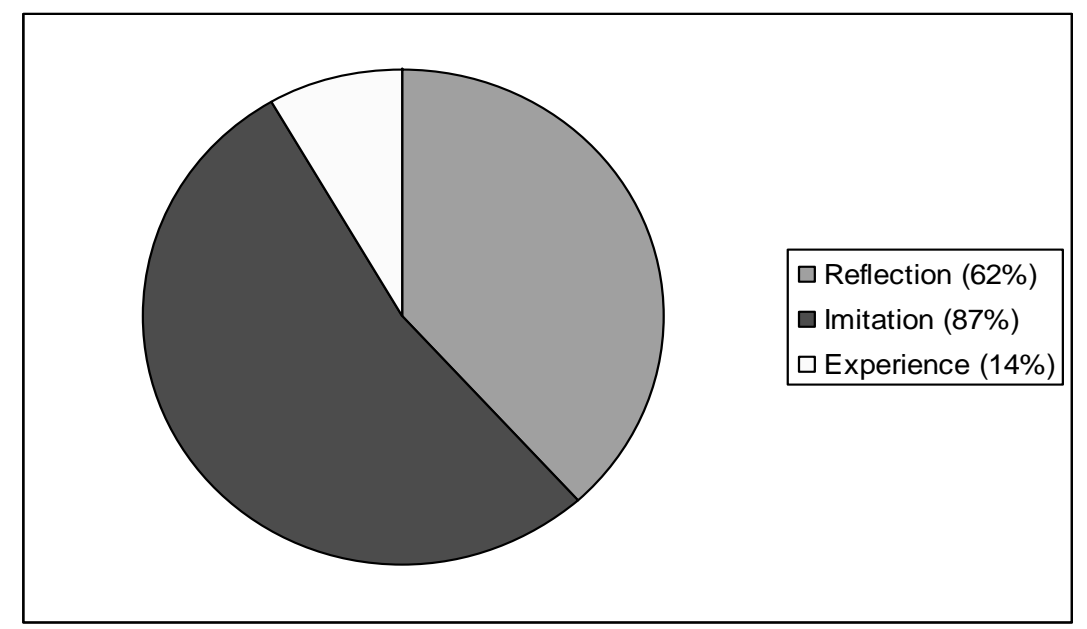

Figure 3: Percent of the total preservice teacher responses $(n=37)$ represented by each Confucian method. 
Preservice teachers' expectations of learning to teach science via Imitation made up the highest percentage of responses, 32 of 37 (87\%). In 23 of the 37 (62\%) total responses, preservice teachers' expected to learn through Reflection within the science methods course. Experience, as reported in the results above, appears to be of lowest expectation as a means through which preservice teachers will learn to become science teachers. Only $14 \%$ of the responses (5 of 37) were categorized into this group.

\section{DISCUSSION}

Kirschner, et al. (1993) reported that students enter science content courses with expectations of what they will encounter. Those expectations influence their perceptions of what they actually did encounter throughout the course. It is possible that preservice teachers' perceptions of the content, teaching strategies, and learning activities in our methods course are determined by the expectations they had upon entry to the course. Our research found that preservice teachers expect that they will learn through different modes. These expectations were placed into categories, using the framework of Confucius' teaching about the pursuit of wisdom: Reflection, Imitation, and Experience. Most teacher candidates from this study expected to gain wisdom with these in combination. This is a good sign for teacher educators as the preservice teachers in this study seem to have an understanding that learning to teach is a complex craft which can not be learned strictly by any one of the three methods. It is interesting to note that Experience, the one mode of gaining wisdom deemed by Confucius to be the bitterest (Hall et al., 2008), was mentioned the least by these preservice teachers. The science methods courses at both colleges require a field experiences and teaching of lessons to peers as well as school-aged children. While preservice teachers may know this requirement of the course exists, they seem to not give this method of gaining wisdom and learning much merit in comparison to Reflection and Imitation. While it is understandable they would not expect to learn by Experience alone during the course, it is strikingly absent from their expectations. Based on Kirschner's et al. (1993) research, does this mean that teacher educators should be concerned about preservice teachers not recognizing their field experiences as a potential activity for gaining wisdom about their profession? Further investigation via follow up interviews is warranted on this question.

Confucius asserts that Imitation is the easiest method for acquiring wisdom (Hall et al, 2008). This one method of gaining wisdom was mentioned more than the other two, and appeared $87 \%$ of the time. Preservice teachers were specifically expecting the methods instructor to design and implement hands-on activities in which they could participate and imitate in the future within their K-6 classroom. While Imitation is the easiest method to gain wisdom, it is imperative that preservice teacher educators acknowledge this expectation and provide opportunities for it to be embraced. While Imitation is the easiest method to gain wisdom, it is imperative that preservice teacher educators acknowledge this expectation and provide opportunities for it to be embraced. We should be explicit in our encouragement of Imitation as only a stepping stone to be used in conjunction with Experience and Reflection for preservice teachers to develop their wisdom of science teaching.

Reflection is a pervasive goal in teacher education programs across the nation. The cognitive aspects of reflection that are needed to plan, implement, and assess of a lesson provides the depth of thought that helps preservice teachers develop wisdom. Students in both courses expected to learn via activities that required reflection on some part of the teaching process: planning, implementation or assessment.

In this study, we used an open ended question instrument to elicit expectations elementary preservice teachers held regarding the elementary science methods course they were beginning. Responses were categorized into three groups that align with the Confucian teachings of gaining wisdom. The results of this study suggest that preservice teachers arrive at the science methods course with expectations of how they will learn to become science teachers. The majority of the responses indicated that preservice teachers expected to learn how to teach science by imitating the professor and reflecting over the nature of teaching and learning science. However, the majority of preservice teachers did not seem to anticipate that teaching science as part of the course would help them gain wisdom on how to become an elementary science teacher. This is both surprising and concerning. The absence of expecting experiential learning to teach science is surprising as this is a methods course, similar to methods courses in other content areas, that incorporate peer teaching and field experiences as activities of the course. Since preservice teachers at both institutions responded to the expectation questions before seeing the course syllabus, the 
responses are free of any influence the syllabus and professor explanation of the content of the syllabus would create. This is relevant as the elementary science methods course is traditionally in the semester or two prior to student teaching. This is concerning as the preservice teachers seem to expect a 'how to' manual on how to teach science as modeled by the professor, yet do not truly involve themselves in the process except as a participant and observer. When exactly do they expect to employ these newly learned tricks of the trade before heading off to the field for the real deal? It is through future research in the form of post-surveys and interviews that will further these questions.

\section{CONCLUSIONS}

Science teacher educators plan their elementary science methods courses with activities to help preservice teachers acquire wisdom for becoming an elementary science teacher. These activities typically include watching course instructors, peers, and classroom professionals teaching science lessons; providing the experience of actually teaching science lessons; and giving opportunity for reflection through personal insight. Preservice teachers' expectations of which of these will help them to learn how to teach science will vary from only one to all three. This study has identified these expectations and positioned them within the Confucian modes for gaining wisdom: Imitation, Experience, and Reflection. It is clear that preservice elementary teachers' expectations of learning to become elementary science teachers fall into one of these modes for gaining wisdom. We contend that these expectations should be acknowledged by science teacher educators and deliberately integrated into the design, organization, and implementation of their science methods course. Further, science teacher educators should be diligent and explicit to their students in defining all methods for gaining wisdom in our science methods courses. Although the literature is sparse in regards to preservice teachers' pre-course expectations of their science methods class, this study finds that these expectations do exist. It is from these expectations that a preservice teachers' perceived learning experience within the science methods course will emerge. It is important to help preservice teachers see the value in the interaction and relationship of Reflection, Imitation, and Experience on their journey to

learn to teach science while honing their craft in the process. As preservice teacher educators it is essential that we provide the opportunities for students to recognize and practice these three methods of gaining wisdom within our science methods course.

\section{AUTHOR INFORMATION}

Richard Hechter is a secondary level physics and biology instructor at the University of Winnipeg Collegiate, and an adjunct professor at the University of North Dakota where he teaches elementary science methods in the Department of Teaching and Learning. He can be contacted at rphechter@gmail.com.

Lynette McGregor is an instructor in the Biology Department at Wartburg College (Iowa) where she teaches elementary science methods, secondary science methods, and non-majors science content courses in Biology, Physics and Earth Science. She can be contacted at lynette.mcgregor@ wartburg.edu.

\section{REFERENCES}

1. Allgood, W., Risko, V., Alvarez, M., \& Fairbanks, M. (2000). Factors that influence study. In R. Flippno, \& D. Caverly (Eds.), Handbook of college reading and study research (pp. 201-219). Mahwah, NJ: Lawrence Erlbaum Associates.

2. Anderson, R. D. (1997). The science methods course in the context of the total teacher education experience. Journal Science Teacher Education, 8(4), 269-282.

3. Bargh, J. A., \& Schul, Y. (1980). On the cognitive benefits of teaching. Journal of Educational Psychology, 72(5), 593-604.

4. Bleicher, R., \& Lindgren, J. (2005). Success in science learning and preservice science teaching selfefficacy. Journal of Science Teacher Education, 16(3), 205-225.

5. Brinthaupt, T. (2004). Providing a realistic course preview to on-line students. Teaching of Psychology, 21, 104-106. 
6. Bullough, R., \& Gitlin, A. (1994). Challenging teacher education as training: Four propositions. Journal of Education for Teaching, 20(1), 61-81.

7. Calderhead, J. (2006). Reflective teaching and teacher education. In D. Hartley, \& M. Whitehead (Eds.), Teacher Education. New York, USA: Routledge.

8. Cochran-Smith, M. (2001). Higher standards for prospective teachers: What's missing from the discourse? Journal of Teacher Education, 52(3), 179-181.

9. Dewey, J. (1933). How we think: A restatement of the relation of reflective thinking to the educative process. Boston: D.C. Heath.

10. Fendler, L. (2003). Teacher reflection in a hall of mirrors: Historical influences and political reverberations. Educational Researcher, 32(3), 16-25.

11. Habermas, J. (1973). Knowledge and human interests. London: Heinemann.

12. Hall, G. E., Quinn, L. F., \& Gollnick, D. M. (2008). The joy of teaching: Making a difference in student learning. Toronto, Canada: Allyn and Bacon.

13. Hatton, N., \& Smith, D. (1995). Reflection in teacher education: Towards definition and implementation. Teaching and Teacher Education, 11(1), 33-49.

14. Hawkins, D. (1990). Defining bridging the gap. In E. Duckworth, J. Easley, D. Hawkins, \& A. Henriques (Eds.), Science education: A minds-on approach for the elementary years (pp. 97-139). Hillsdale, NJ: Lawrence Erlbaum.

15. Hoban, G. (2000). Using a reflective framework to study teaching-learning relationships. Reflective Practice, 1(2), 165-182.

16. Jarrett, O. S. (1998). Playfulness: A motivator in elementary science teacher preparation. School Science and Mathematics, 98(4), 181-187.

17. Kelly, J. (2000). Rethinking the science methods course: A case for content, pedagogy, and informal science education. International Journal of Science Education, 22, 755-777.

18. Kirschner, P., Meester, M., Middelbeek, E., \& Hermans, H. (1993). Agreement between student expectations, experiences, and actual objectives of practicals in the natural sciences at the Open university of The Netherlands. International Journal of Science Education, 15(2), 175-197.

19. Melville, W., Fazio, X., Bartley, A., \& Jones, D. (2008). Experience and reflection: Preservice science teachers' capacity for teaching inquiry. Journal of Science Teacher Education, 19, 477-494.

20. Mueller, A., \& Skamp, K. (2003). Teacher candidate talk: Listen to the unsteady beat of learning to teach. Journal of Teacher Education, 54(5), 428-440.

21. Remedios, R., Lieberman, D., \& Benton, T. (2000). The effects of grades on course enjoyment: Did you get the grade you wanted? British Journal of Educational Psychology, 70(3), 353-368.

22. Schon, D. (1983). The reflective practitioner: How professionals think in action. New York: Basic Books.

23. Torff, B. (1999). Tacit knowledge in teaching: Folk pedagogy and teacher education. In R. Sternberg, \& J. Horvath (Eds.), Tacit knowledge in professional practice. Mahwah, NJ: Lawrence Erlbaum Associates.

24. Wagner, M., \& Gansemer-Topf, A. (2005). Learning by teaching others: A qualitative study exploring the benefits of peer teaching. Landscape Journal, 24(2), 198-208. 


\section{APPENDIX A}

\section{Expectations of an Elementary Science Methods Course}

Please consider each question carefully and write out your answers as completely as possible. You may use the reverse side or extra paper if needed.

1- What specific things do you expect to learn from this methods course?

2- What do you expect for activities that will help that learning take place?

3- What do you expect the instructor to do to help you learn?

4- What are the expectations of yourself to learn?

5- When you think of yourself as an elementary teacher, do you think of yourself as a science teacher that teaches other subject areas, or another (ie: reading, math, etc.) type of teacher that also teaches science? Explain your answer.

6- On a scale of 1 (low) to 5 (high), how would you rate your confidence in your ability to teach science?

7 - On a scale of 1 (low) to 5 (high), how would you rate your confidence that your students of the future will learn science effectively as a result of your teaching? 


\section{NOTES}

